\title{
The End of the Old and the Birth of a New Order, 1918-1919'
}

\begin{abstract}
Резуме
Конец старого і народжыня ся нового порядку, 1918-1919

Сеса статя односит ся до років 1918-1919 і довершаючых ся товды в Європі вельох політычных змін, в ефекті котрых медженародне соспільство звернуло увагу на Карпатскых Русинів і іх отчызну, Карпатску Русь. Автор омавлят пару вічи зорганізуваных през Карпатскых Русинів в Пілнічній Америці і Європі, на котрых раджено над можливыма будучыма сценариями для Карпатской Руси: або як незалежной державы, або зєднаной з Росийом, Украіном, Уграми ци Чехословацийом. Што правда, на мирній конференциі в Парижи выбрано чехословацкій вариянт, єднак в медженародных умовах поминены остали лемківскы Русины, якых лишено під польском властю.
\end{abstract}

Ключовы слова: Карпатска Русь, самостановліня народів, русиньскы імігранты в Америці, мирна конференция в Парижи, Лемкы

\section{Streszczenie}

Koniec starego i początek nowego porządku, 1918-1919

Przedmiotem niniejszego opracowania są lata 1918-1919 i zachodzące wówczas w Europie ogromne zmiany polityczne, w wyniku których społeczność

From: Magocsi, Paul Robert. 2015. With Their Backs to the Mountains. A History of Carpathian Rus' and Carpatho-Rusyns. Budapest-New York: Central European University Press, pp. 175-190 , chapter 13. 
międzynarodowa zwróciła uwagę na Karpatorusinów i ich ojczyznę, Ruś Karpacką. Autor omawia kilka wieców zorganizowanych przez Karpatorusinów w Ameryce Północnej i Europie, na których dyskutowano nad możliwymi przyszłymi scenariuszami dla Rusi Karpackiej: bądź istniejącej jako niezależne państwo, bądź też tworzącej jedność z Rosją, Ukrainą, Węgrami lub Czechosłowacją. Wprawdzie na konferencji pokojowej w Paryżu zdecydowano się na wariant czechosłowacki, jednak łemkowskich Rusinów pominięto w umowach międzynarodowych i pozostawiono, by żyli pod polską władzą.

Słowa kluczowe: Ruś Karpacka, samostanowienie narodów, rusińscy imigranci w Ameryce, konferencja pokojowa w Paryżu, Łemkowie

By 1915, the second year of World War I, the conflict had reached a stalemate. The opposing armies faced each other along fronts which, despite steadily high casualties, did not move in any significant manner. Occasionally there might be an offensive surge by one side, as with the Russian advance during the summer of 1916 that brought far eastern Galicia and Bukovina once again under tsarist control, but within a few months the front lines returned more or less to where they had been before. The year 1917 did bring, however, two events of significance that were to have a profound impact on the outcome of the war. In April, the United States entered the war on the side of the Allies, providing them with military supplies and soldiers that helped reinforce the Western Front. In February and again in October of that year, the Russian Empire experienced two revolutions. The February Revolution toppled the tsar and brought an end to imperial rule; the October Revolution brought to power radical revolutionaries, known as Bolsheviks, who immediately set out to create what they claimed would be the world's first socialist state-Soviet Russia.

\section{National self-determination and socialist revolution}

These two developments had important political and military ramifications that were played out in early 1918. In January of that year, President Woodrow Wilson of the United States announced his country's war aims in a 14-point 
declaration. The declaration proposed the creation of a Polish state and also called for autonomy for the various peoples of the Habsburg Empire. In yet another document Wilson spoke of the right of all peoples for "national self-determination."2 In other words, each nationality had an inalienable right to govern itself. Wilson's views were adopted by the Allies which meant that among their war aims was the political transformation-although not dismantlement-of Austria-Hungary.

The second development was played out in what after October 1917 became Bolshevik-ruled Soviet Russia. The Bolsheviks were a small but tightly organized socialist party, which called for the overthrow of tsarist and later of parliamentary-style democratic rule in Russia. After they carried out a putsch (they called it a "revolution") and took over the reins of government in October/November 1917, they made good on their promise to pull Russia out of the war and to sign a peace treaty (at Brest-Litovsk) with Germany and Austria-Hungary in March 1918. As a result, Germany and its ally Austria-Hungary no longer had to fight along the Eastern Front. This meant that the Central Powers were spared any military threats from Russia, which in any case was soon plunged into civil war between the Bolshevik "Reds" and the so-called "Whites"-all those elements in the former Russian Empire who refused to live in an increasingly dictatorial Soviet state.

The Bolshevik Revolution and Russian Civil War also had an important impact on the tens of thousands of Austro-Hungarian prisoners of war who were released from captivity in late 1917. Among the released soldiers were thousands of Carpatho-Rusyns who witnessed how it was possible to topple an imperial regime and take power into their own hands. Ideas about socialism and certainly the end to feudal-like conditions in the Russian Empire, where the Bolsheviks encouraged the confiscation of the property of large landowners, proved to be attractive to young Carpatho-Rusyn soldiers, mostly of peasant origin. Some even voluntarily joined various armies and partisan units, whether the revolutionary Reds or counterrevolutionary Whites, fighting in Russia's Civil War. Certainly those who returned home in 1918 brought back to Carpathian Rus' convictions about the need for social and political change that they saw was possible from the experience of Russia.

2 This phrase, originally used by Wilson in a May 1916 address to the League to Enforce Peace, was not included in the Fourteen-Point Declaration and was something that later the president stated he regretted having said. Cited in O'Grady, Joseph P. ed. 1967. The Immigrants' Influence on Wilson's Peace Policies. Lexington: University of Kentucky Press, p. 73. 
The March 1918 Treaty of Brest-Litovsk signed between Soviet Russia and the Central Powers also recognized the independence of several countries along the western borders of the former Russian Empire. Among those new countries was Ukraine, which was placed under the protection of Germany and Austria-Hungary, and from which the Central Powers began to extract foodstuffs and grain to send to their own starving populations on the home front.

All these factors made it possible for the leading Central Powers, Germany and Austria-Hungary, to carry on the war. By the summer of 1918, however, it was becoming increasingly evident that the Allies-now with the direct participation of the United States-were going to be the victors. Nevertheless, despite the increasingly weak military position of Germany and Austria-Hungary, both those states remained territorially intact, so that the Habsburg government was able to maintain authority over its empire until the very last weeks of the war. Ever since the imperial parliament was reconvened in May 1917, national activists, at least in the Austrian half of the empire, were able to debate in public various proposals to transform the internal structure of the empire. On the other hand, those activists who favored a complete break with the Habsburgs could only speak out abroad among exiles living and working in Allied countries such as Britain, France, and most especially the United States.

\section{Rusyn Americans mobilize politically}

Carpatho-Rusyns were among the many immigrant groups from central and eastern Europe who followed closely military and political developments in their homeland during World War I. Most of their information came from Rusyn-language newspapers that were published weekly, in some cases several days a week, by the various brotherhood societies. While it is true that in contrast to other Slavic immigrants-Poles, Czechs, Slovaks, and Croats-Rusyn Americans began to engage in organized political activity relatively late, in the end they turned out to be even more successful in achieving their goals than were fellow Slavic-American groups who had started earlier. For example, in a comparative assessment of the impact of President Woodrow Wilson's policies on postwar Europe, the respected Slovak- American historian of the Habsburg Empire, Victor S. Mamatey, concluded that "the Ruthenian 
[Carpatho-Rusyn] immigrants in America did determine the fate of their compatriots at home-a unique case, it appears, of the influence of an immigrant group in America on the political history of Europe."3

The first Carpatho-Rusyn immigrants to organize for a political purpose were the Lemkos from Galicia, in particular the Greek-Catholic-turned-Orthodox priest Joseph Fedoronko, and the newspaper editor Victor Hladick, who during the war years was active in the Lemko and Galician Russophile community in western Canada. In July 1917, Fedoronko helped organize in New York City the first congress of the League for the Liberation of Carpatho-Russia/Soiuz osvobozhdeniia Prikarpatskoi Rusi. The League's goal was to unite with a democratic Russia all the Rus' peoples of Austria-Hungary; that is, Carpatho-Rusyns as well as Galician and Bukovinian "Russians." The League promoted this idea until early 1919 , by which time it became clear that the cause of democracy in the former tsarist empire was lost, and that a Soviet Russia, which had come into being in the interim and which the immigrant groups opposed, was here to stay.

More representative and eventually more decisive were those Rusyn-American organizations comprised primarily of immigrants from the Prešov Region and Subcarpathian Rus' in the Hungarian Kingdom. In July 1918, the representatives of the largest fraternal brotherhoods, the Greek Catholic Union and United Societies, met in the steel-mill town of Homestead, a suburb of Pittsburgh in western Pennsylvania, to form the American National Council of Uhro-Rusyns. The council, representing specifically Carpatho-Rusyns from the Hungarian Kingdom, adopted a resolution calling for autonomy within the Hungarian Kingdom, or, if borders were to change, to be united with their Rus' brethren in Galicia and Bukovina. Considering subsequent developments, it is interesting to note that this first resolution of the Uhro-Rusyn National Council made no mention of joining with Czechs and Slovaks, whose own immigrant leaders were very active at the time. In the presence the wartime's most influential "Czecho-Slovak" exile, Tomáš Garrigue Masaryk, they signed in May 1918 what came to be known as the Pittsburgh Agreement, which guaranteed autonomy for Slovakia in a proposed independent Czecho-Slovak state. Carpatho-Rusyn spokespeople were angered that the Slovaks claimed all of eastern Slovakia, including the Rusyn-inhabited Prešov Region and the city of Uzhhorod, as part of Slovakia in the proposed joint state with the Czechs.

\footnotetext{
Mamatey, Victor S. “The Slovaks and Carpatho-Ruthenians," in ibid., p. 249.
} 
Rusyn-American demands on behalf of their homeland became clarified after the arrival on the scene of Gregory Zhatkovych. Zhatkovych, who held a law degree from the prestigious Ivy League University of Pennsylvania, was at the time an attorney for the General Motors Corporation. Although he was the son of Pavel Zhatkovych, the founding editor of the Greek Catholic Union's influential newspaper, Gregory never played any role in Rusyn-American civic life before the late summer of 1918. From then on, however, he became a decisive figure, especially after the American National Council of Uhro-Rusyns asked him to act on their behalf in promoting their interests with the United States government.

Zhatkovych proved to be remarkably successful in this regard. He drew up a memorandum outlining Carpatho-Rusyn political intentions and, because of connections from his university years, was able to present it in a personal meeting at the White House with President Wilson on 21 October 1918. Zhatkovych's memorandum included three alternatives, but the first and clearly most important one demanded "that our Uhro-Rusyns be recognized as a separate people and, if possible, as completely independent." Other alternatives included unification on the basis of full autonomy with an unnamed neighboring Slavic people or, in the worse case scenario-if prewar borders were to remain unchanged-autonomy within Hungary. Presumably, President Wilson considered a Carpatho-Rusyn independent state unrealistic and proposed instead that Zhatkovych consult with other Slavic political activists.

Zhatkovych acted quickly. Within a few days he met in Philadelphia (at the Mid-European Union, 23-26 October) with the soon-to-be chosen president of Czechoslovakia Tomáš G. Masaryk, with whom he discussed the possibility of including Carpatho-Rusyns within that new state. The expectation was that Carpatho-Rusyns would receive full autonomy in a Czechoslovak federation. At Zhatkovych's initiative, the American National Council of Uhro-Rusyns convened in Scranton, Pennsylvania on 12 November and resolved to seek unity with Czechoslovakia, making clear, however, that the Rusyn-inhabited Prešov Region claimed by Slovaks would be part of an autonomous Carpatho-Rusyn political entity. What became known as the Scranton Resolution was approved by President Wilson as well as by then-elected (in absentia) president of Czechoslovakia, Tomáš G. Masaryk, who suggested that a democratic referendum be held among Rusyn Americans in order to enhance the resolution's

4 Cited in Žatkovič, Gregory I. 1921. Otkrytie-Exposè a Podkarpatskoj Rusi. Homestead, p. 1. 
legitimacy. In December 1918, 68 percent of Rusyn Americans (through indirect voting by delegates of the leading brotherhood organizations) voted for unification with Czechoslovakia. Interestingly, 28 percent voted for union with Ukraine, but only 2 percent for independence, with even smaller percentages for union either with Russia or Hungary. ${ }^{5}$

\section{Political mobilization in the Carpatho-Rusyn homeland}

About the same time that the Rusyn-American communities were reaching specific decisions about their homeland, Carpatho-Rusyns in Europe also began to mobilize politically. Political action was now possible in a situation where Habsburg rule was rapidly disintegrating. During the last days of October, as the new states of Czechoslovakia and Yugoslavia were claiming large blocks of Austro-Hungarian territory, the last Habsburg emperor, Karl I, abdicated, and on 3 November the imperial army signed an armistice of surrender. In effect, the centuries-old Habsburg Empire ceased to exist.

Thereafter, events unfolded in rapid succession. During the first two weeks of November three other states came into existence-Ukraine, Poland, and Hungary-each of which was to have a direct impact on Carpathian Rus'. On 1 November 1918, the day after the last Habsburg emperor abdicated, the Ruthenians/Ukrainians in eastern Galicia declared their independence and in L'viv formed what became the West Ukrainian National Republic. This republic claimed as its territory all the East Slavic/Ruthenian lands of former Austria-Hungary; that is, Galicia east of the San River, northern Bukovina, and all of Carpathian Rus' on both slopes of the mountains. Two months later, in January 1919, the West Ukrainian Republic proclaimed its union with the Ukrainian National Republic based in Kiev, which a year before had declared its independence from Russia. The very day, 1 November 1918, on which Galician Ukrainians declared their independence, they found themselves in armed conflict with local Poles for control of the regional capital of L'viv. Eleven days later, when an independent Poland was proclaimed in Warsaw, its government declared all of Galicia an integral part of its historical patrimony.

Data of the American Uhro-Rusin Commission reproduced in Danko, Joseph. 1964-68. "Plebiscite of Carpatho-Ruthenians in the United States Recommending Union of Carpatho-Ruthenia with the Czechoslovak Republic". Annals of the Ukrainian Academy of Arts and Sciences in the United States 11, no. 1-2: 191-202. 
The conflicting views over Galicia led to a full-scale war between Poland and the West Ukrainian Republic that was to last for the next eight months. Galicia's Lemko Region was, therefore, caught between the conflicting Polish and Ukrainian claims on its territory.

Meanwhile, south of the mountains, anti-Habsburg Hungarian leaders proclaimed an independent republic on 16 November. Although the new republic's government led by Count Mihály Károly was liberal in orientation and open to cooperation with the country's many national minorities, it was at the same time determined to maintain the historic boundaries of the Hungarian Kingdom, including all of Slovakia and Carpathian Rus' on the southern slopes of the mountains. This policy was to bring the Hungarian republic into conflict with other states which laid claim to the Carpathian region, in particular Czechoslovakia and Romania.

In the rapidly changing political circumstances accompanying the collapse of Austria-Hungary, Carpatho-Rusyns were also quick to act. Aware of the Wilsonian doctrine of national self-determination, which was believed to be the policy of the victorious Allied Powers, Carpatho-Rusyn leaders in Europe convoked national councils in much the same way that their immigrant brethren had begun to do a few months earlier in the United States. Also, like the immigrants, the national councils in Europe considered basically the same political options: autonomous self-rule, full independence, or unity either with Russia, Ukraine, Czechoslovakia, or, if necessary, remaining with Hungary. Within the six-month period between 8 November 1918 and 8 May 1919, numerous national councils were established throughout all parts of Carpathian Rus': the Lemko Region, the Prešov Region, Subcarpathian Rus', and the Maramureş Region. In their search for the optimal solution, local leaders were by the outset of 1919 drawn toward four political orientations: (1) unification with Russia; (2) unification with Czechoslovakia; (3) remaining with Hungary; and (4) unification with Ukraine. In two cases, when a given council's desire proved unachievable, it proclaimed an independent state, such as the Lemko-Rusyn Republic in Florynka (December 1918-March 1920) and the Hutsul Republic in Iasynia (January-June 1919). To be sure, none of the Carpatho-Rusyn national councils was acting in isolation; rather, each was influenced by, and trying to maneuver among, the newly formed surrounding political entities that competing to take control of Carpathian Rus'.

In the Lemko Region, several national councils arose in November 1918; they favored basically two differing political goals. In the eastern town of 
Komańcza (Rusyn: Komancha), a self-governing executive council was formed, which intended to join the West Ukrainian National Republic. Within less than two months, however, as Galicia's Poles and Ukrainians were engaged in war for control of the former Austrian province, the Polish Army disbanded the Komancha Lemko "republic" in January 1919. Geographically more widespread was the second orientation comprised initially of four councils representing all seven districts in the Lemko Region. On 5 December 1918, delegates from these councils met in the western Lemko Region village of Florynka, were they formed an Executive Council of the Lemko Region, referred to in some circles as the Rus' National Republic (Russkaia narodnaia respublyka) and headed by the Greek Catholic priest Mykhail Iurchakevych, which coordinated an administration comprised of district-level councils throughout Lemko-inhabited lands from the district of Nowy Targ in the west to Sanok in the east. Initially, the Executive Council hoped to unite the Lemko Region with a democratic Russia. When, however, in early 1919 it became clear that Russia was politically incapacitated by the civil war between the Bolshevik Reds and anti-Bolshevik Whites, the Lemko Rusyns turned instead to their brethren in the Prešov Region with the goal to join them in uniting with Czechoslovakia. Despite the openly stated desire of the Lemko-Rus' leaders not to be part of Poland, the authorities in Warsaw, on the cusp of gaining control of all of Galicia, did not yet intervene directly or try to halt Lemko "separatist" activity.

On the southern slopes of the mountains, Carpatho-Rusyn leaders in the Prešov Region were torn between "uniting with Rus'/Ukraine" - as was proclaimed at a national council held at Stará L'ubovňa on 8 November 1918-or uniting with the new state of Czechoslovakia. ${ }^{6}$ Eventually, the faction led by the Prešov lawyer Antonii Beskyd, and in cooperation with Lemko-Rusyn activists from Galicia, formed a national council in Prešov on 21 December 1918. By that time Czechoslovak troops had reached eastern Slovakia, and their presence inspired confidence among the members of the Prešov Carpatho-Rusyn National Council, which in early January 1919 proclaimed openly its desire to unite with Czechoslovakia.

From the questionnaire distributed by the Russka Narodna Rada, represented by the priest, Emilian Nevyts'kyi, reproduced in Peška Zdeněk; Markov, Josef. 1931. "Příspěvek v ústavním dějinám Podkarpatské Rusi”. Bratislava 5: 526. 


\section{Hungary's autonomous Rus' Land}

Meanwhile, the republic of Hungary under Mihály Károlyi was doing its best to maintain the country's historic boundaries along the crests of the Carpathians. The republic's minister responsible for nationalities, the distinguished sociologist and liberal political activist Oszkar Jászi, was quite serious about providing some sort of self-rule for Hungary's minorities. In fact, the Hungarian government did find willing partners among leading Greek Catholic clerics in Subcarpathian Rus'. On 9 November 1918, the priests Petro Gebei (the future bishop of Mukachevo), Avhustyn Voloshyn (the future head of Carpatho-Ukraine), and Simeon Sabov (canon of the Mukachevo Eparchy), convened in Uzhhorod a Council of the Uhro-Rusyn People, which declared that "the Uhro-Rusyn people do not wish to separate from Hungary . . . but expect to receive all the rights that a democratic Hungary intends to provide to all of its non-Magyar peoples."

Convinced that it had the support of local Carpatho-Rusyn leaders, especially those in the influential Greek Catholic Church, the Károly government adopted on 21 December 1918 a law (No. 10), which called into existence an autonomous province called Rus'ka Kraina (the Rus' Land). The Hungarian law provided for a Rus'ka Kraina Ministry in Budapest and an administration based in Mukachevo; the latter was to be governed temporarily by an advisory council (Rus'ka rada) of 42 representatives from four counties (Ung, Bereg, Ugocha, and Maramorosh) headed by Orest Sabov and Agoshton Shtefan. Provisions were also made for a Rusyn National Assembly/Rus'kyi narodnyi soim, whose 36 elected members actually convened in early March in Mukachevo. Aside from the above four counties (roughly the equivalent of Subcarpathian Rus'), Rus'ka Kraina was expected to include the Rusyn-inhabited parts of Zemplyn, Sharysh, Spish, and Abov counties in the Prešov Region, although that could occur only after the conclusion of a general postwar peace among the various states to emerge from former Austria-Hungary. In fact, the Károlyi regime never fixed the boundaries of Rus'ka Kraina, which alienated the members of the recently elected national assembly (soim).

Cited from the proclamation, “A Magyarországi Rutének Néptanácsától/Ot Radŷ Uhro-rus’koho naroda", 10 December 1918, archive of the Carpato-Ruthenica Library, University of Toronto. 


\section{The Ukrainian option}

Hungary's efforts to retain Carpatho-Rusyn lands were challenged not only by pro-Czechoslovak Rusyn activists, but also by local leaders in far eastern Maramorosh county, in particular its Hutsul region. As early as 8 November 1918, Hutsuls under the leadership of Stepan Klochurak met in the large Subcarpathian mountain village of Iasynia to form a Hutsul National Council. Like the Lemkos in the far northwest of Carpathian Rus', Hutsuls in the far east created a governing administration (with Klochurak as "prime minister") to replace the departing Hungarian authorities and also a self-defense military unit. By January 1919 that unit was about 1,100 strong, comprised of demobilized Austro-Hungarian soldiers from the Hutsul region itself as well as several hundred others who came from Galicia where they were serving with the armies of the West Ukrainian National Republic. The connection with Galicia was significant, since the national council of what was subsequently dubbed the "Hutsul Republic" hoped to unite with the West Ukrainian Republic and become part of a Greater (Soborna) Ukraine.

As for the nearby West Ukrainian Republic, which was already engaged in an intense struggle with Polish forces for control of Galicia, it was in no position to assist the Hutsul Republic. Nor did the West Ukrainians wish to clash with Hungary and Romania, both of which claimed authority over Hutsul-inhabited Subcarpathian Rus'. When, in early January, the Hutsul military units moved toward the town of Maramorosh-Sighet, where a national council favoring unity with Ukraine had just completed its deliberations, they were driven back by Romanian troops.

While the Hutsul Republic continued to administer several mountainous villages near Iasynia, yet another national council convened in Maramorosh county, this time at Khust, on 21 January 1919. Under the leadership of two brothers, Iulii and Mykhailo Brashchaiko, the Khust council's resolution proclaimed that "all Rusyns-Ukrainians in Maramorosh, Ugocha, Bereg, Ung, Zemplyn, Sharysh, Spish, and Abov-Torna counties [i.e., Subcarpathian Rus' and the Prešov Region] unite with Greater (Soborna) Ukraine." The resolution also expressed the desire that "Ukrainian military forces [presumably from the West Ukrainian National Republic] occupy territory inhabited by the Rusyns-Ukrainians of Hungary."

8 Resolution of the Khust National Council, cited in Ortoskop. 1924. Derzhavni zmahannia Prykarpats'koï Ukrä̈ny. Vienna, p. 21. 
In the end, neither the Ukrainian nor the Hungarian option had any real hope of success. On the northern slopes of the Carpathians, Polish armies succeeded by June 1919 in driving the West Ukrainian National Republic and its army out of eastern Galicia. The Allied Powers then authorized Poland to occupy that former Austrian province. Although technically the occupation was only on a temporary basis, the Poles immediately proceeded to set up an administration and to treat all of Galicia, including the Lemko Region, as if it were already part of Poland.

As for the Hungarians, they were fully compromised in the eyes of the victorious Allies when, in March 1919, Károlyi’s government fell and was replaced by a Bolshevik-style Soviet government headed by Béla Kun. Even Hungary's autonomous province of Rus'ka Kraina based in Mukachevo was in late March transformed into Soviet Rus'ka Kraina. This short-lived experiment marked the first attempt at establishing Communist rule in some part of Carpathian Rus', even though the head (commissar) of Soviet Rus'ka Kraina was a holdover from the Károlyi regime, the decidedly anti-Communist Agoshton Shtefan. Nevertheless, a government council (uriadova rada) was elected in early April 1919, and it, together with the already existing national assembly (soim), even adopted a constitution for Soviet Rus'ka Kraina within the framework of the Hungarian Soviet Republic. Clearly, all these efforts at self-rule for Carpatho-Rusyns were linked to the political fate of Hungary.

\section{Carpatho-Rusyns on the international stage}

In early 1919, when the victorious Allied Powers led by the United States, Great Britain, and France convened a conference in Paris to determine the postwar political order in Europe, one of the major concerns facing the peacemakers was Bolshevik Russia and its proclamations about a socialist world revolution which was slated to spread first to central Europe. Bolshevik predictions seemed to be fulfilled with the appearance of Béla Kun's Soviet Hungary. Therefore, to prevent the further spread of Bolshevik-style revolutions, the Allies authorized and gave military assistance to Czechoslovak and Romanian forces to enter the lands of historic Hungary from the west and from the east.

It was in the context of the offensive against Soviet Hungary that Romanian troops took all of Maramorosh county and in June 1919 dismantled the "independent” Hutsul Republic. By August 1919 Béla Kun’s Soviet experiment in 
the heart of the Danubian Basin was crushed, with the result that two-thirds of historic Hungary's territory was in the hands of other states. The Rusyn-inhabited lands in former northern Hungary were now under the control of Czechoslovak troops (the Prešov Region and western Subcarpathian Rus') and Romanian troops (Subcarpathian Rus' east of Mukachevo).

Carpatho-Rusyn political activists quickly adapted to these new political realities. Those who had favored the Hungarian and Ukrainian options now joined with their compatriots in the Prešov Region and the Lemko Region in support of the Czechoslovak solution. A Rusyn-American delegation headed by Gregory Zhatkovych arrived in Uzhhorod in March 1919 and proceeded to convince local pro-Hungarian sympathizers about the advantages of joining Czechoslovakia. The result was a gathering in Uzhhorod on 8 May 1919 of some 200 delegates who represented the previous councils at Prešov, Uzhhorod, Khust, and the Lemko Region, and who now formed the Central Rusyn National Council. After a week of deliberations, chaired by the former pro-Hungarian supporter, Avhustyn Voloshyn, the Central Rusyn National Council in Uzhhorod declared that it endorsed the memorandum of the Rusyn-American delegation; namely that "Rusyns will form an independent [nezavysymŷi/nezávislý] state within a Czecho-Slovak-Rusyn republic." The Rusyn-American Zhatkovych was clearly the most authoritative figure at the Uzhhorod gathering, with the result that the Central Rusyn National Council's resolutions reflected his views on what was expected to be a self-governing "Uhro-Rusyn state," whose borders were to be determined by mutual agreement "with representatives of the "Czecho-Slovak republic," and which in "all governing and internal matters was independent [Czech: samostatný]." 10

The only losers at Uzhhorod were the Lemko Rusyns. Just a few weeks before, the Lemkos, as part of the pro-Czechoslovak national council in Prešov, submitted a memorandum (together with a map) to the Paris Peace Conference, requesting that the Lemko Region not be separated from Rusyns south of the Carpathians and together with them be made an "autonomous part of the Czecho-Slovak Republic."11 But the Central Rusyn National Council in

9 Cited from the Czech and Rusyn texts of the resolutions adopted of the last day of the Central Rusyn National Council, Uzhhorod, 16 May 1919, reproduced in Peška Zdeněk; Markov, Josef. 1931. "Příspěvek v ústavním dějinám Podkarpatské Rusi”. Bratislava 4, pp. 419 and 421.

10 Ibid.

11 The Origin of the Lems, Slavs of Danubian Provenance: Memorandum to the Peace Conference Concerning Their National Claims, signed by Anthony Beskid and Dimitry Sobin for the National Council of the Carpathian Russians at Prešov, 20 April 1919, p. 23. 
Uzhhorod, at the urging of Zhatkovych, rejected the Lemko request to join their brethren in what the Rusyn-American activist called: "Uhro-Rusinia, the proposed third state of the Czechoslovak republic." 12

To be sure, Carpatho-Rusyn demands were one thing, but political realities could be something else. Czechoslovakia's interest in Rusyn-inhabited lands south of Carpathians was something very recent, having begun when the country's founding president, Tomáš Garrigue Masaryk, was approached in late 1918 by Carpatho-Rusyn immigrants in the United States. Before that time Masaryk never even considered Carpatho-Rusyn inhabited territory, as evidenced by the eastern boundary line he proposed in 1915 for a future Czechoslovak state (see Map 23). But by 1918 Masaryk's views had evolved and were linked to larger geopolitical concerns in which the soon-to-be president hoped that his small central European country could find solace in having a powerful ally like Russia, whether or not it was ruled by Bolsheviks. With that political constellation in mind, Subcarpathian Rus' seemed an ideal bridge to the east, especially if the borders of Russia or the Soviet Union would ever reach the crests of the Carpathians.

In the interim, Czechoslovakia had to deal with the local Carpatho-Rusyn population, and therefore it did incorporate the basic decisions of the Uzhhorod Central Rusyn National Council as part of its territorial proposals submitted to the international peace conference which was meeting in various palaces just outside Paris during the spring of 1919. The treaty which fixed Czechoslovakia's borders was adopted at Saint Germain-en-Laye on 10 September 1919. This international agreement specified that "the Ruthene territory south of the Carpathians" was to be endowed with "the fullest degree of self-government compatible with the unity of the Czecho-Slovak state." ${ }^{13}$ Just what compatibility meant and what was the extent of the "Ruthene territory" being promised self-government were issues that still needed to be clarified. As we shall see, there were no easy solutions to these questions.

As for the eastern boundaries of Czechoslovakia, they were defined by the Treaty of St. Germain and reiterated in the Treaty of Trianon concluded nearly a year later (4 June 1920) with Hungary. All of Slovakia and Carpatho-Rusyn lands south of the mountains were now recognized by the international community as part of Czechoslovakia. Most of Hungary's political and

12 Title of a map prepared by the Rand McNally Company in the United States.

13 Traité entre les Principales Puissances Alliées et Associées et la Tchécoslovaquie, Paris 1919, Article 10 , p. 26. 
civic leaders were appalled by Trianon, which reduced Hungarian territory to a mere one-third of what it had been within the Habsburg Empire. Over 3.3 million Magyars (31 percent of the total at the time) suddenly found themselves as minorities in states that at best were barely tolerant of them. ${ }^{14}$ Almost immediately a political movement began in Hungary known as irredentism; that is, an attempt to get back territories taken away by what Magyars everywhere considered the punitive Treaty of Trianon.

As for the Lemko Region, it together with all of Galicia was initially assigned by the peacemakers in Paris to Poland, but only on a temporary basis. Eventually, however, the Allied and Associated Powers grew tired of the "Galician Question," and in March 1923 they formally recognized all of the former Habsburg-ruled province of Galicia to be a part of Poland. Before the status of Galicia was finally clarified, the Lemko Rusyns, whose request to join Czechoslovakia was turned down in May 1919, managed to maintain a degree of control over their homeland north of the Carpathians for nearly another year. During that time Lemko leaders tried to reach some kind of accommodation with the Polish government. When negotiations broke down, their Executive Council gathered again in Florynka, and on 12 March 1920 formally proclaimed themselves the Supreme Council of the Rus' National Republic of Lemkos under the leadership of Prime Minister Iaroslav Karchmarchyk. The Supreme Council set out to govern the territory it claimed, which was later popularly remembered as the Lemko-Rusyn Republic. The Polish government responded immediately by sending an armed force to disperse the "republic" and establish its own administration throughout the Lemko Region.

The only other part of historic Carpathian Rus' was a small territory that included the town of Sighet (the recent site of a Rusyn national council) and several nearby villages along the northern bank of the Tisza River and its tributaries in far southern Maramorosh county. The decisions at the Paris Peace Conference assigned this small area to Romania.

Hence, following the close of World War I and the disappearance of Habsburg-ruled Austria-Hungary, historic Carpathian Rus' found itself divided by international boundaries and under the rule of three states: Poland, Czechoslovakia, and Romania. There were also scattered and isolated Rusyn-inhabited villages in parts of post-Trianon Hungary and of Yugoslavia (the

14 "Demographic Losses of the Kingdom of Hungary Due to World War I," in Eberhardt, Piotr. 2003. Ethnic Group and Population Changes in Twentieth-Century Central-Eastern Europe. Armonk- London: Routledge, p. 291. 
Vojvodina and Srem, see below, Chapter 17). The subsequent fate of Carpatho-Rusyns was to differ significantly depending on which state they inhabited during the two so-called interwar decades of the twentieth century.

\section{Literature}

Danko, Joseph. 1964-1968. "Plebiscite of Carpatho-Ruthenians in the United States Recommending Union of Carpatho-Ruthenia with the Czechoslovak Republic". Annals of the Ukrainian Academy of Arts and Sciences in the United States 11, no. 1-2: 191-202.

Eberhardt, Piotr. 2003. Ethnic Groups and Population Changes in Twentieth-Century Central-Eastern Europe: History. Data and Analysis. Armonk-London: Routledge. https://doi.org/10.4324/9781315704470.

Magocsi, Paul Robert. 2015. With Their Backs to the Mountains. A History of Carpathian Rus' and Carpatho-Rusyns. Budapest-New York: Central European University Press.

Mamatey, Victor S. 1967. "The Slovaks and Carpatho-Ruthenians". In: The Immigrants' Influence on Wilson's Peace Policies. Ed. Joseph P. O'Grady. Lexington: University of Kentucky Press.

O'Grady, Joseph P., ed. 1967. The Immigrants' Influence on Wilson's Peace Policies. Lexington: University of Kentucky Press.

Ortoskop. 1924. Derzhavni zmahannia Prykarpats'koï Ukraïny. Vienna.

Peška Zdeněk; Markov, Josef. 1931. "Příspěvek v ústavním dějinám Podkarpatské Rusi". Bratislava 4: 419, 421.

Peška Zdeněk; Markov, Josef. 1931. "Příspěvek v ústavním dějinám Podkarpatské Rusi”. Bratislava 5: 526.

The Origin of the Lems, Slavs of Danubian Provenance: Memorandum to the Peace Conference Concerning Their National Claims, signed by Anthony Beskid and Dimitry Sobin for the National Council of the Carpathian Russians at Prešov, 20 April 1919.

Traité entre les Principales Puissances Alliées et Associées et la Tchécoslovaquie, Paris 1919, Article 10.

Žatkovič, Gregory I. 1921. Otkrytie-Exposè a Podkarpatskoj Rusi. Homestead. 